\title{
LENDING AND INVESTMENT PRACTICES OF COMMERCIAL BANKS*
}

\author{
George W. Coleman $\dagger$
}

I

The investment and lending practices and policies of the commercial banking system change relatively slowly. Standards and practices which have proved successful in making loans to finance the production of goods and services or in investing funds in governmental and corporate securities continue to be utilized. Frequent modifications of lending practices are not needed since the financing needs of business and industry change slowly. Some change is, however, discernible. Some successful lending practices have been adapted to meet the new financing needs of industry and commerce. In some cases, new techniques of lending have been devised in order to extend credit to finance new types of business. The terms and conditions under which certain types of loans can be made have been altered by federal or state legislation. Recently, the laws have been modified to permit banks to invest in entirely new types of securities, e.g., World Bank Securities. Moreover, the existence of a large public debt has changed markedly the investment policies of the commercial banking system. Changing tax policy has also influenced trends in investment practices.

For the purpose of analyzing the contemporary trends in the lending and investment practices of commercial banks, the end of World War II can be taken as a convenient date from which to start. It would, however, be incorrect to imply that the policies and practices discussed in the following pages are "new," that is, developed and employed for the first time since the end of the war. These lending and investing practices are discussed because they are being employed by more and more commercial banks. It should be emphasized that they supplement the older and better known methods; they have not replaced them.

The lending and investment practices and policies of the commercial banking system have been influenced by the postwar monetary and fiscal policies followed by the Treasury Department and the Federal Reserve System. It is, therefore, impossible to discuss contemporary trends in lending and investment policies without referring to the policies followed by the central banking system and the Federal Government. It is equally impossible to discuss these policies at length since they are beyond the scope of this paper. ${ }^{1}$

- Statistics in this article have been prepared by Eugene M. Meentemeyer.

+Economist, Mercantile Trust Company, St. Louis, Mo. Formerly Assistant in Economics, Washington University, St. Louis, Mo. The opinions expressed herein are those of the author.

${ }^{1}$ This subject has been discussed in the Annual Reports of the Federal Reserve Board of Governors and in hearings before the various Congtessional Committees. 
Contemporary trends and developments in the lending and investment practices of commercial banks can best be described by tracing the history of commercial banking in the postwar period. The second and third sections of this paper, therefore, analyze the statistics available showing developments in the loans and investments of the commercial banking system. The fourth section is devoted to a discussion of some of the new types of loans which have been used widely since the end of the war and some legal aspects which have influenced the making of such loans. As was stated earlier, the lending practices of commercial banks in the postwar period have been influenced by banking legislation. The fifth section is, therefore, devoted to a discussion of the changes in laws, mainly federal laws, which govern lending and investment practices. The sixth section is devoted to a summary of the main currents in commercial banking in the postwar period, while in the final section reference is made to some proposals which may influence the commercial banking system in the future.

II

The financing of World War II resulted in a rapid expansion of bank credit. ${ }^{2}$ From June 30, I940 to December 3r, I945 the Federal Government spent about 380 billion dollars. Of this, 153 billion dollars came from taxes and the remainder was borrowed; 133 billion dollars was borrowed from investors, and the rest-more than 95 billion dollars - was borrowed from commercial banks and the Federal Reserve banks. Thus, about 40 per cent of the Government's expenditures was raised by taxes while the remainder was borrowed. Total loans and investments of all commercial banks rose from 40.7 billion dollars at the end of $x 939$ to 124 billion dollars at the end of r945. During that period loans rose from 17.2 billion dollars to $26 . \mathrm{x}$ billion dollars, and a substantial part of this increase resulted from $\mathrm{V}$ loans and loans to finance the purchase of United States Government securities. United States Government securities held by commercial banks rose from $I 6.3$ billion dollars to 90.6 billion dollars.

Total LoANS AND INVESTMENTS OF ALI COMMERCial BANKS

(In millions of dollars)*

\begin{tabular}{|c|c|c|c|c|}
\hline \multirow[b]{2}{*}{ Date } & \multirow[b]{2}{*}{ Total } & \multirow[b]{2}{*}{ Loans } & \multicolumn{2}{|c|}{ INVESTMENTS } \\
\hline & & & $\begin{array}{c}\text { U. S. Government } \\
\text { Securities }\end{array}$ & $\begin{array}{c}\text { Other } \\
\text { Securities }\end{array}$ \\
\hline 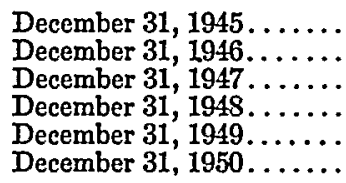 & $\begin{array}{l}124,019 \\
113,993 \\
116,284 \\
114,298 \\
120,197 \\
126,675\end{array}$ & $\begin{array}{l}26,083 \\
31,122 \\
38,057 \\
42,488 \\
42,965 \\
52,249\end{array}$ & $\begin{array}{l}90,606 \\
74,780 \\
69,221 \\
62,622 \\
67,005 \\
62,027\end{array}$ & $\begin{array}{r}7,331 \\
8,091 \\
9,006 \\
9,189 \\
10,227 \\
12,399\end{array}$ \\
\hline
\end{tabular}

*37 Rev. Res. BoLr. 527 (1951).

2 The data included in this section, as' well as the following section, are based upon information contained in the Annual Reports of the Board of Governors of the Federal Reserve System and the Federal Deposit Insurance Corporation. 
During the early part of 1946 , the steady expansion of bank credit came to a halt. The Treasury reduced its budgetary deficit substantially and used the large balance accumulated in the Victory War Loan Drive to pay off bankheld debt. Since then, with an interruption in 1948, commercial bank credit has steadily increased. The defense program undertaken after the beginning of hostilities in Korea has resulted in a further expansion of loans.

The table shows what has happened to commercial bank loans and investments since the end of the war. From the table it is clear that the postwar period has been characterized by a tendency to shift funds from investment in United States Government securities into loans. While this tendency is significant, equal importance must be attached to the shifts in the types of loans and investments made in the postwar period.

In order to show what the lending activities of the commercial banking system have been since the end of the war, it is necessary to examine trends in the various kinds of loans. The most comprehensive information concerning the various types of loans is available from data covering the member banks of the Federal Reserve System. Almost one-half of the commercial banks in the United States are members of the Federal Reserve System and these banks hold about 85 per cent of the total loans and investments of all commercial banks. Consequently, statistics of the member banks probably reflect fairly accurately the trends of the whole banking system. In certain cases the Federal Deposit Insurance Corporation has compiled data covering all insured banks and this information has also been used.

Released from wartime restraints, industries producing goods for the civilian market expanded rapidly and bank loans rose commensurately. By the end of 1946 total loans of all commercial banks amounted to $3^{\text {T.I }}$ billion dollars-the highest level reached since 1930. In I946 member bank loans to business and industry had risen more than 4 billion dollars, or more than $5^{\circ}$ per cent. Commercial banks also engaged in extensive lending on mortgages. During 1946 , non-farm mortgages under $\$ 20,000$, recorded, totalled ro.6 billion dollars of which 2.7 billion dollars were recorded by commercial banks. ${ }^{3}$ Commercial bank loans on farms also expanded.

The vigorous expansion in bank loans continued in 1947 , and by the end of that year two new records had been established. In 1947 bank loans expanded 7 billion dollars, and at the end of the year total commercial bank loans exceeded the figure reached at the end of $r 929$.

Loans to commercial and industrial borrowers increased by almost the same amount that they had increased in 1946. Thus, in the first two postwar years loans to commerce and industry had almost doubled. While normal working capital requirements accounted for a part of the increase in loans, a great part of the increase in business loans resulted from the financing of a large volume of plant and equipment expenditures. The higher price level also accounted for a part of the increase.

\footnotetext{
${ }^{3}$ Housing Statistics 22 (Housing and Home Finance Agency, Washington, D. C., I95r).
} 
Urban real estate loans also expanded as banks continued to handle a substantial volume of home mortgages. At the end of 1947 urban mortgage loans of insured banks totalled 8.5 billion dollars, slightly more than 25 per cent of all loans. Moreover, the commercial banks handled a slightly larger volume of total mortgages under $\$ 20,000$, recorded.

Consumers also utilized bank credit to finance the purchase of durable consumers' goods. These loans were largely for the purchase of automobiles and household appliances as well as for the repair and modernization of existing dwellings. The sales finance companies also borrowed funds to finance the expanding volume of consumer borrowing. Loans for the purchase or carrying of securities declined additionally in 1947 . At the end of 1945 loans for this purpose had totalled more than 6.7 billion dollars. Individuals, corporations, and institutional investors had borrowed heavily in order to purchase United States Government securities in the Victory Loan Drive occurring near the end of 1945 , and these loans were liquidated in the succeeding years. During 1946 this total was cut in half and by the end of I947 there was a further decline of about I billion dollars. During I946 a roo per cent margin was required for the purchase or carrying of listed securities. This margin requirement had been established on January 21, I946. On February I, 1947 the margin requirements were reduced to 75 per cent.

Total loans of commercial banks continued to expand in 1948 although the increase was not so great as in 1947. During that year business loans declined less than seasonally in the first half of the year and then began to rise rather sharply. In the last quarter of 1948 loans to business remained relatively stationary. For the entire year bank loans to business increased only 0.7 billion dollars. This increase tended to be concentrated in the New York City and the Southwest and Pacific Coast regions. Bank loans to business did not rise so much as in previous years because business was able to borrow a large amount of funds from insurance companies, from the capital market, and from other non-bank sources. A declining price level also reduced the demand for bank credit.

Banks were not so active in 1948 in lending money to real estate owners. As a result, real estate loans increased only $\mathrm{I} .4$ billion dollars. Loans to consumers continued to advance rapidly until the Federal Reserve Board re-imposed Regulation W in September, x948. Loans by banks accounted for nearly one-half of the increase in the volume of loans made to consumers in that year.

Agricultural loans had not in the preceding two years increased by any sizable amount but this was not true in 1948 . In that year the total agricultural loans of insured commercial banks rose from 1.6 billion dollars to 2.8 billion dollars. This increase resulted from the sharp decline in the prices of agricultural commodities which occurred in I948. The banks loaned money to the farmers to carry these commodities; these loans were guaranteed by the Commodity Credit Corporation.

In order to restrain inflationary tendencies, Congress in August, 1948 authorized 
the Board of Governors of the Federal Reserve System to increase the reserve requirements of member banks. This authority was granted only on a temporary basis and it expired on June 30, I949. ${ }^{4}$ Under this authority the Board was authorized to increase the required reserve against time deposits of all member banks to 7.5 per cent. At the same time the Board was authorized to increase the required reserve against demand deposits to not more than 30 per cent for central reserve city banks, 24 per cent for reserve city banks, and 18 per cent for all other member banks. In September the Board of Governors raised the required reserve against time deposits to the maximum amount -7.5 per cent. In the same month the reserve requirements of member banks against demand deposits were raised two percentage points. Country banks were required to carry a 16 per cent reserve against their demand deposits while reserve city banks were required to carry a 22 per cent reserve. The central reserve city banks experienced an increase in their reserve requirements to 26 per cent. At no time did the Board of Governors increase required reserves by the full amount allowed by the Joint Resolution. The same Joint Resolution authorized the Board to re-impose controls on the financing of the purchase of durable consumers' goods.

In the first half of I949 business activity declined quite sharply and the volume of bank loans made to commercial and industrial borrowers also declined. In the latter half of the year, however, a rapid expansion began and bank loans rose sharply. While they did not recover all the volume lost, they were, at the end of the year, more than 900 million dollars above the low reached early in August.

In part, the decline resulted from a liquidation of inventories and a lower level of industrial activity, and many borrowers again obtained funds from the private and public flotation of securities.

In the first half of the year loans to consumers were limited by Regulation W. The Federal Reserve Board liberalized the terms governing consumer installment financing in March and again in April. The Regulation expired June 30, 1949. In the last half of the year loans to consumers rose sharply. For the year, total installment indebtedness increased 2.3 billion dollars. The consumer loans made by all insured commercial banks advanced in that year 1.2 billion dollars.

For the entire year I 949 the volume of real estate lending was nearly equal to the level reached in the preceding two years. The larger part of the activity in I949, however, was concentrated in the last half of the year. As a result, total real estate loans advanced during the year, increasing almost 700 million dollars to 11.4 billion dollars at the end of the year.

At the end of 1949 the total loans of all banks in the United States and possessions amounted to more than 49.8 billion dollars. Of these loans 36 per cent were real estate ones while 34 per cent were commercial and industrial. The next largest category was other loans to individuals, principally consumer loans, which accounted

${ }^{4} 62$ STrT. 1291 (1948), 12 U. S. C. 5462 (c) (Supp. 1950). 
for 16 per cent of all loans. On that date commercial banks held loans partially guaranteed by various agencies of the Federal Government amounting to 8.I billion dollars, the guaranteed portion of which was 5.9 billion dollars. Of the guaranteed loans, real estate loans accounted for the largest part. These loans totalled 5.6 billion dollars and the guaranteed portion was approximately 4.2 billion dollars. The guaranteed real estate loans were almost equally divided between loans guaranteed by the Federal Housing Administration and loans guaranteed by the Veterans Administration. Almost the entire amount of F.H.A. loans held by the commercial banks was guaranteed but slightly less than half of the total amount of the GI loans was guaranteed. Farm loans, of course, was the next largest category of guaranteed loans. The banks held approximately I billion dollars of loans totally guaranteed by the Commodity Credit Corporation. ${ }^{5}$

Loans to farmers advanced in 1949 nearly 200 million dollars, about half of which was represented by loans directly guaranteed by the Commodity Credit Corporation. Loans for the purchase and carrying of securities increased about 300 million dollars in 1949 .

Nineteen fifty was a critical year in the field of commercial banking. In the first half of the year business activity expanded and total bank loans of all commercial banks increased 1.6 billion dollars. The outbreak of the Korean war, almost at midyear, stimulated a very rapid expansion in business activity. Consumers, retailers, and manufacturers all bought heavily in anticipation of higher prices and restrictions in production. In the last half of the year bank loans expanded sharply.

Business borrowing at the banks in the first half of $195^{\circ}$ declined as usual, but because business activity was increasing, the decline was less than seasonal. In the last half of the year loans to business expanded rapidly to permit borrowers to carry inventory and to purchase agricultural commodities. In $195^{\circ}$ the commercial banks loaned I2 billion dollars to consumers on an installment basis to finance the purchase of automobiles, home appliances, and similar items. This was about half the increase reported in this type of credit. Commercial banks expanded their holdings of home and other real estate mortgages by more than 2 billion dollars in I950 to reach a new peak of 13.5 billion dollars. At the end of the year the commercial banks held about 25 per cent of all the real estate mortgages held by institutional investors.

The accompanying table ${ }^{6}$ shows the trends in the principal types of loans of all banks in the United States and possessions for the first 6 postwar years.

In the first part of $195 \mathrm{I}$ total loans of the weekly reporting member banks expanded. The expansion in real estate loans was relatively small as was the case with loans for the purchasing and carrying of Government securities. Commercial

- Annual Report of the Federat Deposit Insurance Corporation for the Year Ended December 3I, 194935 .

Id., 1950, at 38 . 
Princtpal Types of Loans of all Banks in the United States and Possessions, DECEMBER, I945-I950

\begin{tabular}{|c|c|c|c|c|c|c|c|}
\hline December 31 & $\begin{array}{l}\text { All } \\
\text { loans } \\
\text { gross }\end{array}$ & $\begin{array}{l}\text { Com- } \\
\text { mercial } \\
\text { and } \\
\text { industrial }\end{array}$ & $\begin{array}{c}\text { Agri- } \\
\text { cultural } \\
\text { excluding } \\
\text { real estate }\end{array}$ & $\begin{array}{l}\text { Real } \\
\text { estate }\end{array}$ & $\begin{array}{c}\text { For } \\
\text { carrying } \\
\text { securities }\end{array}$ & $\begin{array}{c}\text { Other } \\
\text { loans to } \\
\text { individuals }\end{array}$ & $\underset{\text { other }}{\text { All }}$ \\
\hline 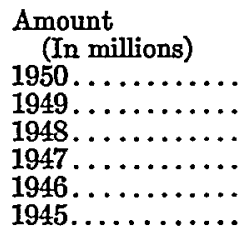 & $\begin{array}{r}\$ 61,638 \\
50,615 \\
49,090 \\
43,231 \\
35,823 \\
30,467\end{array}$ & $\begin{array}{r}\$ 22,068 \\
17,195 \\
19,055 \\
18,295 \\
14,237 \\
9,600\end{array}$ & $\begin{array}{r}\$ 2,926 \\
3,075 \\
2,893 \\
1,678 \\
1,412 \\
1,361\end{array}$ & $\begin{array}{r}\$ 21,925 \\
18,350 \\
16,703 \\
14,302 \\
11,675 \\
8,980\end{array}$ & $\begin{array}{l}\$ 2,882 \\
\mathbf{2}, 658 \\
2,332 \\
2,075 \\
3,164 \\
\mathbf{6 , 8 2 7}\end{array}$ & $\begin{array}{r}\$ 10,243 \\
8,159 \\
6,960 \\
5,791 \\
4,109 \\
2,419\end{array}$ & $\begin{array}{r}\$ 1,594 \\
1,178 \\
1,147 \\
1,090 \\
1,226 \\
1,280\end{array}$ \\
\hline $\begin{array}{l}\begin{array}{l}\text { Percentage } \\
\text { distribution }\end{array} \\
1950 \ldots \ldots \ldots \ldots \\
1949 \ldots \ldots \ldots \ldots \\
1948 \ldots \ldots \ldots \ldots \\
1947 \ldots \ldots \ldots \ldots \\
1946 \ldots \ldots \ldots \ldots \\
1945 \ldots \ldots \ldots \ldots\end{array}$ & $\begin{array}{l}100.0 \% \\
100.0 \\
100.0 \\
100.0 \\
100.0 \\
100.0\end{array}$ & $\begin{array}{l}35.8 \% \\
34.0 \\
38.8 \\
42.3 \\
39.8 \\
31.5\end{array}$ & $\begin{array}{l}4.7 \% \\
6.1 \\
5.9 \\
3.9 \\
3.9 \\
4.5\end{array}$ & $\begin{array}{l}35.6 \% \\
36.3 \\
34.0 \\
33.1 \\
32.6 \\
29.5\end{array}$ & $\begin{array}{l}4.7 \% \\
5.2 \\
4.8 \\
4.8 \\
8.8 \\
22.4\end{array}$ & $\begin{array}{l}16.6 \% \\
16.1 \\
14.2 \\
13.4 \\
11.5 \\
7.9\end{array}$ & $\begin{array}{l}2.6 \% \\
2.3 \\
2.3 \\
2.5 \\
3.4 \\
4.2\end{array}$ \\
\hline
\end{tabular}

Gross loans include raluation reserres.

loans did not decline seasonally. On the other hand, they expanded sharply through the first quarter to reach at least a temporary plateau.

At the end of July, I95I commercial, agricultural, and industrial loans began to rise seasonally. By the end of August they had reached 19.4 billion dollars, an increase of more than 500 million dollars.

\section{III}

The investment policies of the commercial banking system have undergone some change in the postwar period. During the war, the commercial banking system invested large amounts of money in United States Government securities in order to provide funds to finance the high level of wartime expenditures. In the postwar years the policy of investing in Government securities was reversed, and the banking system sold securities in order to secure funds to lend to business and individual borrowers.

In 1946 the most significant development in bank investment policy was the sharp decline in the volume of Government securities held by the commercial banks. It has already been noted that the Victory Loan Drive ended late in I945 and the Treasury had accumulated large balances as a result of that drive. Since these funds were not needed to finance war expenditures, the Treasury employed them to reduce the volume of the public debt outstanding. Thus, from the end of 1945 to the end of 1946 the total public debt was reduced from 278 billion dollars to 259 billion dollars. This decrease resulted in a decline of 22.5 billion dollars in the General Fund. Apart from the redemption of these holdings, banks also sold 
Government securities in order to restore their reserve positions and to obtain funds to meet demands for loans. Late in the year there was some upward pressure on rates.

In May, x946, the Federal Reserve System terminated the preferential discount rate on advances to member banks secured by Government securities maturing or callable within one year. This preferential rate of $1 / 2$ of I per cent had been established as a wartime measure in October, 1942. The Federal Reserve Board abandoned this policy in order to restrain credit expansion.

The long-term market was characterized in the spring of 1946 by a sharp decline in the yield of Government securities. Immediately after the close of the Victory Loan Drive, the Victory 2-1/2 per cent bank-restricted issue of December, 1967-72 began to rise in price. In April the price had reached 106-1/2; at this price the yield to the call date was 2.12 per cent. From that date the yield rose. At the end of the year it had reached 2.32 per cent. The intermediate securities followed a similar pattern, and corporate securities also followed this pattern, but by the end of the year the "spread" between the yields on corporate securities and yields on long-term Government securities had widened slightly.

In I947 Treasury operations also influenced bank investments. In that year the Treasury had a surplus, the first Treasury surplus since 1930. This surplus was used to reduce the public debt, and the sale of non-marketable securities provided a sufficient volume of funds to reduce the marketable public debt from I77 billion to 166 billion dollars. During 1947 commercial bank holdings of United States Government securities declined 6 billion dollars. These sales were necessary to restore reserves and to finance an expanding volume of loans.

Interest rates were permitted to rise still further in r947. At mid-year the Federal Reserve System discontinued the practice of buying and selling Treasury bills at a fixed rate of $3 / 8$ of I per cent. This policy had been adopted in 1942. The rate on Treasury bills began to rise slowly thereafter. The certificate rates increased late in the year. On December 24, 1947 long-term Government bond prices were permitted to decline sharply, although the $2-1 / 2$ per cent rate on the longest ineligibles was maintained.

Nineteen forty eight closely paralleled 1947 . Once again the commercial banks disposed of Government securities to restore reserve balances and to finance an expansion in loans. Since reserve requirements were increased, the member banks were forced to sell United States Government securities in order to secure funds to meet the higher reserve requirements. A change in the holding of Government securities also occurred. The banks tended to shift to shorter-term securities. The funds received by the banking system from the redemption of maturing bonds were reinvested in certificates and short-term notes. There was also a tendency to sell longer-term bonds and purchase Treasury bills. Again in 1948 there was a tendency . for interest rates to rise. 
Bank investment in 1949 was influenced by a variety of forces. Reserve requirements were reduced thus releasing funds for investment. The monetary policies of the Federal Reserve System attempted to force rates lower and to provide funds for private borrowers in order to stimulate private business. But near the end of the year it was apparent that economic recovery had begun and a policy of neutrality toward interest rates was adopted by the Federal Reserve System.

In I950 the commercial banks continued to sell securities from their Government bond portfolios in order to obtain funds to meet expanding private loan demands. The banks sold 5 billion dollars, 4 billion dollars of which was sold in the last half of I950. Non-bank investors provided a market for these securities in the first half, but in the last half the Federal Reserve System was the major purchaser.

Another development of importance occurred in the investment policy of commercial banks. In $195^{\circ}$ these banks acquired more than 2 billion dollars of state and local government securities. At the end of the war "other securities," mainly state and local government securities, had totalled 7.3 billion dollars. The following table showed the trend in holding of these securities.

$\begin{array}{lr}\text { December 3I, I946 } & \$ 8.1 \text { billion } \\ \text { December 3I, I947 } & 9.0 \text { billion } \\ \text { December 3I, I948 } & 9.2 \text { billion } \\ \text { December 3I, I949 } & \text { r0.2 billion } \\ \text { December 3I, I950 } & 12.4 \text { billion }\end{array}$

The purchase of these municipal securities had provided a large part of the funds raised by state and local government to finance a variety of postwar projects. In I950, however, some banks purchased municipal securities because these securities are "tax free" and in a period of rising corporate income taxes and excess profits taxes an advantage accrued from their purchase.

In $195^{\circ}$ the interest rate structure moved irregularly higher. Money rates had been eased in $x 949$ as the result of actions by the Federal Reserve System, but the apparent business recovery resulted in the adoption of measures designed to curb credit expansion and raise rates to commercial borrowers. In August, r950 the Federal Reserve System, viewing with concern the expansion of bank credit, undertook a series of measures designed to increase the cost and to restrict the availability of bank reserves. The re-discount rate was raised from $x-1 / 2$ to $I-3 / 4$ per cent. That same month the Federal Reserve System changed its policy with regard to the Government bond market and ceased to maintain a money market in which the Treasury financing could be done at low rates.

In August the Treasury announced that Government securities maturing in September and October would be refunded in 13 -month $1-1 / 4$ per cent notes. The Federal Reserve Open Market Committee purchased more than 8 billion dollars of these maturing securities in order to insure the success of the refunding operation, but at the same time the Federal Reserve System sold other securities at slightly 
higher yields. One result of this policy was the establishment of higher interest rates for Government securities and higher interest rates for commercial borrowers.

Early in March, I95I the Treasury and the Federal Reserve System reached an agreement on policies designed to minimize the monetization of the public debt. The Treasury refunded the longest-term ineligible bonds into non-marketable securities. The Federal Reserve System limited its purchases to short-term securities and yields on Government securities rose. In May the Treasury declined to "call" the 2 per cent bonds of September 195I-53, and rates on Treasury bills rose. One result of these policies was that holders of Government securities were more unwilling to sell them, and the long-term money market was relatively "tight" at mid-year.

\section{IV}

As was stated earlier, in the last few years business has been undergoing changes and it required new types of financing. Among these new techniques are $\mathrm{V}$ loans, term loans, "stand by" commitments, revolving credit loans, accounts receivable financing, equipment financing, and consumer credit loans. In addition, the federal laws were changed in such a manner as to make additional types of real estate mortgages available for bank investment.

In 1940 Congress passed the Assignment of Claims Act. ${ }^{7}$ The objective of this Act was to facilitate the extension of credit to contractors and sub-contractors engaged in the production of military equipment. At that time government contracts were not assignable and apart from these contracts many small contractors had little security which would have been satisfactory collateral for a bank loan. This law was vital to the success of the V Loan Program.

During World War II the Federal Reserve banks acted as agents for the War and Navy Departments and the United States Maritime Commission in guaranteeing war production loans. More than 10.5 billion dollars of war production loans were guaranteed in the period April, 1942 to May, $19466^{8}$ "The guarantee consisted of an agreement made in advance of each loan, by which the procurement agency that required the particular production obligated itself to take over a specified portion of the credit risk at any future time, on demand of the bank or other commercial lending institutions that had made loans with its own funds." Later, the program was amended so that a borrower could arrange in advance to obtain the use of most of his working capital immediately upon the cancellation of the contract and before final settlement. These were called VT loans, and still later the Board was permitted to make termination loans, generally called $\mathrm{T}$ loans.

Within the last few years, however, the Comptroller-General made several rulings which limited the effectiveness of the Assignment of Claims Act. A provision had been incorporated into many of the contracts stating that the contractor agreed to repay any sums received if it was later determined that the price charged was

${ }^{7} 54$ STAT. 1029 (1940), 31 U. S. C. $\$ 203$, 4 I U. S. C. \$15 (1946).

- Susan S. Burr and Elizabeth B. Sette, a Statistical Study or Regulation V loans 3 (1950).

- Annual Report of the Board of Governors of the federai Reserve System 32 (1945). 
excessive. The Comptroller-General ruled that under this provision amounts in excess of the revised contract price might be withheld or, if already paid, recovered from the assignee.

Strictly interpreted, this ruling is correct since the assignee normally has no more rights than the assignor. This ruling, however, made it extremely difficult for a lending agency to finance defense contracts. It meant that a bank, for example, might be subject, long after the termination of a loan, to a claim for repayment of funds which had been received in good faith.

Sometime later the Comptroller-General issued another ruling that interfered with the defense loan program. The Assignment of Claims Act provided that claims under assigned contracts were not to be subject to any offset for claims arising independently of the contract. The Comptroller-General, however, ruled that unpaid social security and withholding taxes, renegotiation liabilities, and similar items did not arise independently of the contract. Consequently, these claims could be offset against claims made by the assignee bank.

These decisions probably caused many banks to refuse to make loans for the production of "defense" goods where contracts were to be assigned as security. The Federal Reserve System amended the standard form of guarantee agreement under the V loan program by recognizing such claims as "losses on the loan,"10 but Congress amended the Act, effective May $15,195{ }^{11}$ to provide relief against these rulings. Payments received by assignees since July $x$, $195^{\circ}$ are not recoverable. The Government, however, retains the right to make claims against the contract assignor or deduct from subsequent payments under the contract amounts determined to be excessive. The amendment states further that renegotiation claims, fines, penalties, and unpaid taxes arise independently of the contract, and claims of this nature cannot be offset against payments due under the contract. ${ }^{12}$

The $\mathrm{V}$ loan program has been revived as a method of financing the production of military goods. Section 301 of the Defense Production Act of $1950^{13}$ authorized the Federal Reserve banks to guarantee loans in a manner similar to that of the original $\mathrm{V}$ loan program. The number of guaranteeing agencies has, however, been considerably enlarged. Now, the Departments of Army, Navy, Air Force, Commerce, Interior, and Agriculture, the General Services Administration, and the Atomic Energy Commission may act as guaranteeing agencies. Briefly, the program functions in this manner. If a defense contractor requires financing in order to carry out the terms of his contract, he makes application to his local bank for a loan. The local bank, if it does not wish to carry the entire loan itself, may make application to the Federal Reserve bank in its district for a guarantee. The Federal

${ }^{10}$ Loan Guarantees for Defense Production, 37 FED. REs. BuLx. 20 (I95I).

${ }^{12}$ Assignment of Claims Against Government, id. at 508. Pub. L. No. 30, 82nd Cong., rst Sess. (May 15, 195I).

${ }^{12}$ Kupfer, Federal Assignment of Claims Act Comes of Age (Public Law No. 9 and Public Law No. 30 of the $82 n d$ Congress), New York Law Journal, June 4, 5, and 6, r95 I.

${ }^{13} 64$ STAT. 800, 50 U. S. C. App. §209I (Supp. 1950). 
Reserve bank is required to submit this loan application to the guaranteeing agency, and if the guaranteeing agency approves, it authorizes the Federal Reserve bank to execute a guarantee in its name. ${ }^{14}$

The maximum interest rate which may be charged is 5 per cent and the maximum commitment fee which can be charged is $1 / 2$ of I per cent. The larger the amount of the guarantee requested the greater is the portion of the interest paid by the borrower which must be remitted to the guaranteeing Federal Reserve bank as a guarantee fee. For a 70 per cent guarantee only ro per cent of the interest paid must be remitted in the form of a guarantee fee. For a 95 per cent guarantee the financing institution must pay 40 to 50 per cent of the interest paid by the borrower to the Federal Reserve bank as a guarantee fee. ${ }^{15}$

The term loan and the "stand by" agreement are probably the most significant and successful innovations developed in bank lending practice in the last 20 years. ${ }^{16}$ The term loan was almost unknown before 1935, but for a number of reasons it developed rapidly after that date. In the first place, there was a demand on the part of small and medium sized businesses for longer term credit than banks normally supplied. It was difficult for these companies to sell bonds on the open market because the Securities and Exchange Commission regulations made such sales expensive. Equity capital could not be secured except on very unfavorable terms, and, later in the period, certain tax advantages resulted from borrowing funds. Furthermore, the extension of term loans was facilitated by actions taken by the banking supervisory authorities. They adopted new methods of classifying loans, and legislation was enacted which broadened the types of assets which could collateralize loans from, or which could be discounted with, the Federal Reserve banks.

By 1940 term loans by banks amounted to more than 2 billion dollars. ${ }^{17}$ Alternate methods of financing during the war slowed the growth in the volume of term loans, but after the war the volume increased sharply. In the last half of 1946 , the Federal Reserve Board made a survey which showed I44,000 term loans outstanding, made by member banks, amounting to 4.6 billion dollars. ${ }^{18}$ While term loans were made to all types of business, loans to manufacturing and mining concerns accounted for more than one-half of the total volume outstanding. Loans to new businesses (organized since 1942) represented a substantial part of loans made to small businesses.

A term loan can be defined as a loan having a maturity in excess of one year, and

\footnotetext{
14 Martin, Federal Reserve Responsibilities Under Defense Production Act, 37 Fed. Res. Butr. 494 (I95I).

${ }_{10}$ Fees and Rates Established Under Regulation $V$ on Loans Guaranteed Pursuant to Defense Production Act of 1950 and Executive Order No. 10161, 37 FED. REs. Burl. 5I7 (I95I).

${ }^{10}$ Herpert V. Prochnow, Term Loans and Theories of Bank Liquidity (Prentice-Hall, 1949); Neil H. Jacoby and Raymond J. Saulnier, Term Lending to Business (National Bureau of Economic Research, I942).

17 JACOBY AND SAULNIER, op. cit. supra, at 30.

${ }^{18}$ Holthausen, Term Lending to Business by Commercial Banks in 1946, 33 Fed. REs. BuLL. 498 517 (1947).
} 
it usually provides for periodic re-payments. It may be secured or unsecured. While a term loan may be made by one bank, frequently a number of banks and other financing institutions join in making such a loan. It has been employed to finance the acquisition of new machinery and equipment. New construction has been financed by term loans.

Since the term loan usually has a longer maturity, the lending banks usually incorporate certain protective covenants in the loan agreement. These covenants relate to the maintenance of minimum working capital, non-pledge of borrower's assets, and limitations on total debt of borrower. Other provisions relate to salaries of management, payment of dividends, etc. In many agreements a provision was incorporated requiring the borrower to anticipate payments when the earnings exceeded a "normal" figure, and such anticipatory payments were credited against the last outstanding maturity.

Interest rates charged on term loans vary. The more common practice seems to be to charge a flat rate of interest which depends upon the credit of the borrower. In a few cases, the term loan agreement provides that higher interest rates are to be charged for the longer maturities. Some term loans have provided for a fluctuating interest rate based upon the rediscount rate.

A modification of the term loan which came into general use shortly after the end of the war is the "stand by" agreement. The borrower under the terms of a "stand by" agreement is not required to borrow the funds immediately but the lender commits himself to advance the funds at any time within a specified period.

The use of the "stand by" agreement developed for a number of reasons. During the war, borrowers, fearing that the settlement of war contracts would be delayed and they would not have funds to finance reconversion to the production of civilian goods, sought commitments from their banks to meet that need. The introduction of VT and T loans delayed the independent development of "stand by" agreements. Borrowers also sought them because the borrower was assured that the money would be available when he needed it and the interest rate would be guaranteed.

"Stand by" agreements usually are a part of a term loan. They are designed to provide funds to cover specific commitments made by the borrower. This procedure enables the borrower to arrange for a loan but to borrow the funds only when they are actually needed. Thus, a builder may arrange to pay for materials and labor as various sections of a building are completed and need not borrow the full amount long before it is actually needed. The agreement specifies a date on which the "stand by" commitment terminates, as well as providing for the conditions of the term loan.

For this commitment the borrower agrees to pay a commitment fee on the unused portion of the loan. At the beginning when interest rates were low, the commitment fee was frequently $1 / 4$ of $\mathrm{I}$ per cent but recently it has been raised in some cases to $1 / 2$ of I per cent. The commitment fee, of course, depends upon the length of time over which the "stand by" agreement is to run and other factors. 
The revolving credit agreement is another modification of the term loan which is now used extensively. A revolving credit agreement permits a borrower to borrow up to a maximum amount for a specific period. During that period the customer may borrow the full amount, repay part of it, and again borrow the entire amount. This type of loan is employed in cases in which the borrower wishes to carry varying amounts of inventory. For example, a tobacco company may utilize a credit of this type to carry tobacco. It has also been used in connection with the financing of defense contracts.

The interest rate charged on the portion used is frequently fixed at a specific figure. In some cases, however, the revolving credit agreement specifies that the interest rate charged shall be the prime rate charged by each bank. Thus, the interest rate charged might be different, if a number of banks participated in the loan. A charge is also made on the unused portion of the credit, and it may vary from $1 / 2$ of I per cent to I per cent, depending upon the borrower, the length of the credit, and other factors.

Within the last decade commercial banks have employed field warehousing receipts as a means of making working capital available to business enterprises which are unable to borrow except on a collateral basis. A field warehouse can be defined as a warehouse established on property leased from the borrowing concern. This warehouse is usually operated by a firm specializing in this type of activity, and it receives the raw materials or finished goods, and issues "field warehouse receipts." In this way inventory can be used as collateral. This type of receipt differs from warehouse receipts issued by terminal warehouses since the goods securing the receipt are usually located on the premises of the borrower. ${ }^{19}$

Another type of financing which has come into wide use is accounts receivable financing. "Accounts receivable financing may be defined as a continuing arrangement through which a financing agency makes funds available to a business concern by purchasing its invoices or accounts receivable over a period of time, or by making advances or loans, taking one or a series of assignments of accounts as primary collateral security."20

One difficulty with this type of financing was that in order to make the assignment valid the debtor had to be notified. Many businessmen disliked to assign accounts under these circumstances because they feared that it would lead to loss of customers. On the other hand, bankers were unwilling to lend on the security of accounts receivable, because the validity of the assignment was doubtful unless the debtor was notified. Many states during the period under consideration amended their laws to make the assignment good if notice was filed with an appropriate state authority.

\footnotetext{
${ }^{10}$ Neil. H. Jacoby and Raymond J. Saulnier, Financing Inventory on Field Warehouse Receipts (National Bureau of Economic Research, I944).

${ }^{20}$ Raymond J. Saulnier and Neil H. Jacoby, Accounts Recetvable Financing I (National Bureau of Economic Research, 1943).
} 
Many other types of loans have been made by banks in the last several years. Housing loans guaranteed by the F.H.A. and modernization loans also guaranteed by the F.H.A. were developed in the pre-war period. Multiple housing loans, guaranteed by the F.H.A., were employed on a large scale during the war and also in the postwar period. Attempts have been made to utilize term lending techniques in order to extend credit to farmers for soil conservation. ${ }^{21}$

\section{$\mathrm{V}$}

In the postwar period inflation has been a recurring problem. From time to time Congress has considered and passed legislation authorizing the Federal Reserve Board to control the extension of various types of credit. At the same time, however, the national banks and the member banks of the Federal Reserve System have been authorized to invest in certain types of securities in order to provide funds to finance the International Bank for Reconstruction and Development and the construction of housing units under public housing authorities.

The control of consumer credit is governed by Regulation W issued by the Federal Reserve System. It specifies the minimum down payment for the purchase of certain durable consumers' goods and limits the length of time over which payments can be made. It was originally adopted in August, $\mathrm{I} 94 \mathrm{r},{ }^{22}$ was amended many times during the course of the war, and was still in effect at the end of the war. It underwent some modification in 1946 , but continued in effect until November $x$, 1947. Congress had specified that termination date in a resolution approved in August. ${ }^{23}$ Nearly one year later the Board was again given power to control the terms under which credit could be extended for the purchase of consumers' goods. This authority lapsed again on June 30 , r $949 .{ }^{24}$ It was not until the outbreak of war in Korea that Congress again authorized the control of consumer credit. ${ }^{25}$ This regulation was made effective September 18 , 1950. In July, I95I Congress enacted legislation extending to June 30, 1952 the authority of the Federal Reserve Board to regulate consumer credit. ${ }^{23}$ The new act specified the maximum "down payment" which could be required and the minimum number of months over which the installment credit could be extended.

In 1949 a number of laws were passed revising the authority of the member banks to invest in certain types of securities. Congress on June 29, I949 authorized national banks and state member banks to deal in and underwrite obligations issued by the International Bank for Reconstruction and Development, provided that the total holdings by any bank do not exceed to per cent of the bank's combined capital and surplus. ${ }^{27}$ Many states have passed similar laws.

\footnotetext{
${ }^{21}$ Darryz R. Francts, Bank Credit for Soll Conservation (Federal Reserve Bank of St. Louis r947).

${ }^{22}$ Exec. Order No. 8843, 6 FEd. Reg. 4035 (194I).

${ }^{23}$ 6I Stat. 921 (1947), 50 U. S. C. App. $\$ 5$ note (Supp. 1950).

2462 STAT. I291 (1948), I2 U. S. C. $\$ 462$ (c) (Supp. 1950).

${ }^{36} 64$ STAT. 812, 50 U. S. C. App. \$2r3r (Supp. 1950).

so Pub. L. No. 96, 82nd Cong., Ist Sess. (Defense Production Act Amendments, 1951).

${ }^{27} 63$ STAT. 298, 439 (1949), 12 U. S. C. 524 (Supp. r950).
} 
Later in 1949 Congress authorized national banks and state member banks to deal in, underwrite, and purchase for their own accounts obligations of local public housing authorities secured by agreements with the Federal Housing Authority. ${ }^{28}$

In I950 the authority of the Federal Reserve Board to regulate loans was extended to cover loans made on new real estate construction when the credit was not insured or guaranteed by any other agency of the Federal Government. Section 602 of the Defense Production Act of $1950^{29}$ authorized the president to regulate loans of this type and he, in turn, delegated his authority to the Federal Reserve Board. The Federal Reserve Board exercised this authority in conjunction with the Housing and Home Finance Administrator. Regulation $X$ was issued by the Board of Governors on October II, I950. This regulation concerned only real estate credit on one- and two-family housing units but on February 15, I95I, the regulation was extended to cover real estate credit on multi-unit residential property and non-residential property.

Reserve requirements have also been the subject of legislation during the postwar period. The Board was empowered for a period from August, I948 to June 30, I949 to raise required reserves above the existing statutory maxima. ${ }^{30}$ The required reserve against time deposits could be raised to 7.5 per cent, while the required reserve against demand deposits of central reserve city banks could be raised to 30 per cent, reserve city banks to 24 per cent, and country banks to 18 per cent. This measure was adopted in order to limit the expansion of bank credit. The Board, as is noted elsewhere, did not impose the maximum requirements, except for required reserves against time deposits.

The Defense Production Act of $195^{\circ}$ authorized the president to permit business enterprises to combine to carry out the objectives of the Act. ${ }^{31}$ One of the objectives of the Act was to restrain inflation by limiting the extension of credit. ${ }^{32}$ The president delegated this authority also to the Board of Governors and under this authority the Board of Governors established the National Voluntary Credit Restraint Committee. The objective of this program was to bring an end to the expansion of credit and to channel credit into those fields in which it would contribute most toward the financing of the defense program and the production of essential goods and services. Originally, representatives of the commercial banking system, the investment banking system, and the life insurance companies participated in the program but it was later expanded to include representatives from the savings and loan associations and from the mutual savings banks.

Through this program the National Voluntary Credit Restraint Committee attempted to classify types of loans which could be made and types of loans which

${ }^{98}$ Ibid.

${ }^{20} 64$ SтAт. 813, 50 U. S. C. App. \$2132 (Supp. 1950).

so 62 Stat. I29I (1948), I2 U. S. C. $\$_{4} 62$ (c) (Supp. 1950).

${ }^{21} 64$ STAT. 8I8, 50 U. S. C. App. \$2158 (Supp. 1950).

${ }^{32} 64$ STAт, 812, 50 U. S. C. App. §2131 (Supp. т950). 
should not be made. Loans to finance defense production were approved and loans for the production, processing, and orderly distribution of agricultural and other staple products were to be permitted. Loans were allowed to augment working capital to the extent necessary to sustain essential production, processing, and distribution services. In making such working capital loans the committee permitted the banks to consider higher wages and prices of materials as reasons for augmenting working capital. Loans to security dealers to carry on their normal business operations were permitted but speculative loans on securities or commodities were condemned. Also disapproved were loans to acquire or retire corporate equities in the hands of the public.

Loans insured, guaranteed or authorized as to purpose by any government agency were exempt from the program because it was believed that the governmental agency involved would authorize such loans in accordance with national policy.

In addition to the initial statement the Voluntary Credit Restraint Committee issued clarifying bulletins from time to time. Bulletin No. I issued March I5, $^{2}$ 95 I concerned the accumulation of inventories. It recommended that bankers refrain from financing abnormal inventory accumulation and encourage borrowers to bring excessive inventories into line with normal requirements as soon as possible.

On April 23, I95I a second bulletin covering recommended restrictions on business capital expenditures financing was issued. The Committee recommended that financing of business capital expenditures be denied where the purpose was to construct or enlarge the facilities of the producers and distributors of non-essential goods. Bulletin No. 3 was issued May 3, I95I. This bulletin urged financing institutions to screen carefully loans to state and local governments. In the judgment of the Committee, government loans to replace existing facilities, to construct facilities not recommended by the Defense Production Administration, and to acquire sites not immediately needed were to be disapproved. Borrowing funds to purchase private utilities by municipalities was also deemed to be inadvisable. In connection with this request Mr. Charles E. Wilson, Director, Office of Defense Mobilization, wrote a letter to all governors, mayors of major cities, and financial officers of principal counties requesting that they delay borrowing money if the contemplated project was postponable.

While Regulation $X$ governed the terms of financing new real estate construction and F.H.A. and V.A. regulations covered the terms and conditions under which insured and guaranteed loans could be made, no credit controls existed on loans made on old construction. On June 14 , I95 1 the National Voluntary Restraint Committee issued Bulletin No. 4 suggesting methods of applying principles of voluntary credit restraint in the field of real estate financing.

In addition to establishing certain general policies, the National Voluntary Credit Restraint Committee also appointed regional sub-committees to which financing institutions could refer loans when they were doubtful about the action which should be 
taken. Originally, a sub-committee was established for commercial banks in each one of the I2 Federal Reserve districts. Subsequently, regional committees were appointed in some districts. Three regional committees were established by the life insurance companies and three regional committees were established by the Investment Bankers Association.

\section{VI}

During the $1933^{\prime}$ 's both the loan and investment policies of the commercial banking system were strongly influenced by the depressed level of industrial activity. Since business was depressed there was little demand for credit, and even those industries receiving credit were screened carefully in terms of "credit-worthiness." During the war, commercial banking policy was dominated by the national policies adopted to finance the conduct of the war.

With the end of the war, commercial banking emerged into a new phase, different from that of either preceding period. The period since the end of the war has been one of rapid industrial expansion, and the volume of construction has been heavy. This expansion resulted in an increased volume of loans. In the period since Korea, governmental expenditures for defense have exerted additional inflationary pressures on the economy. In short, if the decade of the 1930's was characterized by efforts to halt deflation, the period since the end of the war has been characterized by efforts to curb inflation and at the same time to finance a rapid expansion in industrial capacity.

It is true that a high level of industrial activity has improved the financial position of many prospective borrowers. But inflation has forced these same companies to seek bank credit in order to carry on the same "real" volume of business at a higher price level. Judgments of "credit-worthiness" now must include a consideration of the length and intensity of the inflationary period. Bankers are now lending money in an inflationary economy and extreme caution must be used.

Lending policy has also been influenced over the entire period by a tendency for money rates to increase. The demand for money has been great, and interest rates have risen slowly. The increase undoubtedly would have been greater had the Federal Reserve System not attempted to maintain stability in the Government bond market and to maintain the $2-1 / 2$ per cent rate for long-term bonds. This policy arbitrarily held interest rates low and also permitted an uncontrolled expansion in bank reserves. The Federal Reserve System abandoned that policy, despite apparent opposition from the Treasury.

The increasing use of the capital loan also has become a factor in contemporary bank lending policies. Term loans have already been discussed, but reference should also be made to government-guaranteed housing loans. Loans of this type are, of course, older than the postwar period, but they have become more important.

During the war years the commercial banking system of the United States, as 
well as other countries, acquired large amounts of Government securities. Both lending and investment policies have been influenced by this development. In the period before 1929, total investments of all member banks represented about 20 per cent of total assets. After that date loans declined sharply and commercial banks invested a substantial percentage of their total assets in Government securities.

The outbreak of World War II intensified this trend. The Federal Government turned to the commercial banks to sell those securities which could not be sold to other investors. Thus, at the end of 1945 , total assets of all member banks amounted to 138 billion dollars of which 84 billion dollars, or $6 \mathrm{r}$ per cent, was invested in securities. Of this amount 78.3 billion dollars was invested in United States Government securities. Since the end of the war, loans have risen and investments in securities have declined. Currently, United States Government securities represent less than one-half of the total assets of all member banks.

Commercial bankers are following a practice of maintaining a secondary reserve in the form of United States Government securities in addition to the primary reserve required by federal and state laws. The relative size of this secondary reserve as well as its maturity-distribution depends upon a great many factors. However, it is clear that, as his portfolio of United States Government securities decreases toward a predetermined minimum, the banker becomes more and more unwilling to reduce it further in order to make loans.

No fixed pattern has emerged concerning the investment policy followed relative to United States Government securities. Some banks have attempted to "space" their maturities equally over a Io year period, but the majority have probably attempted to maintain as "short" a position as possible. The volume of deposits held in savings accounts has also been a factor in determining the volume of long-term Government securities held by banks.

\section{VII}

Inflationary pressures still exist and they have resulted in new discussions about methods of exercising monetary controls. One of the methods proposed several years ago was the creation of a security reserve as a supplement to the primary cash reserve. The basic objective was to restrict the expansion of credit to business by forcing the banks to maintain a part of their reserves in the form of United States Government securities. It must be realized that a securities reserve requirement will not reduce the multiple expansion of credit in the same manner that an increase in the cash reserve would; it would only direct the type of security in which a part of the expanded credit was to be invested.

Another proposal is for the creation of a loan reserve. It can be described briefly as a proposal to require "every insured bank receiving demand deposits ... to maintain additional reserves equal to a percentage . . . of that part of its loans and in- 
vestments in excess of a certain prescribed base." ${ }^{33}$ The proposed loan reserve plan has not been considered by Congress up to the present time. The loan reserve plan is a proposal for the quantitative control of credit, and it tends to apply unsound standards. A much sounder method of utilizing bank credit to finance the preparedness program and to curb inflationary tendencies can be found in the Voluntary Credit Restraint Program.

${ }^{33}$ Report to the President (submitted by Charles E. Wilson, Director of Defense Mobilization, John W. Snyder, Secretary of the Treasury, William McC. Martin, Chairman of the Board of Governors of the Federal Reserve System, and Leon H. Keyserling, Chairman of the Counsel of Economic Advisers) (May 3I, I95I). 